\title{
Utfordringer ved Münchhausens syndrom
}

\author{
Münchhausens syndrom passer ikke inn i en vanlig somatisk, psykisk eller psykosomatisk sykdomsforståelse \\ og representerer en usedvanlig stor utfordring med henblikk på identifisering, diagnostisering og behandling. \\ Hvordan kan man best hjelpe pasientene?
}

Vi ønsker med dette å rette oppmerksomhet mot en etter vår mening misforstått, underdiagnostisert og feilbehandlet tilstand, nemlig Münchausens syndrom. Vi har alle mangeårig erfaring med behandling av pasienter med dette syndromet og ønsker å bidra til økt oppmerksomhet om og større forståelse for disse pasientene og hvordan vi best kan hjelpe dem.

Betegnelsen «Munchausen's syndrome» ble introdusert av den engelske psykiateren sir Richard Asher i 1951, oppkalt etter baron von Münchhausen, en tysk adelsmann fra 1700-tallet som var kjent for sine fantasifulle historier (1). Ifølge ICD-10 er Münchhausens syndrom rubrisert under F68.1: Viljestyrt produksjon eller simulering av symptomer eller dysfunksjon, enten fysisk eller psykisk.

\section{Etiologi og komorbiditet}

Ved Münchausens syndrom formodes at det bak atferden ligger et underliggende ønske om oppmerksomhet, medlidenhet, sympati og eventuell vanedannende medisin (forutsatt at sistnevnte ikke er hovedmotivet). Trangen kan gå så langt at pasienten samtykker i og til dels ønsker invasive undersøkelser og operative inngrep selv om det medfører risiko for komplikasjoner, smerter og ubehag.

Muligens kan nysgjerrighet på hvordan leger vil reagere ved neste sykehusopphold og maktutøvelse forbundet med spenning og overlegenhetsfølelse overfor et rådløst helsepersonell tenkes å være medvirkende. I enkelte tilfeller synes hevntanker overfor helsearbeidere, som resultat av negative opplevelser ved tidligere sykehusopphold, å spille en rolle. Mange av pasientene arbeider innenfor helsevesenet (2), noe som er blitt forklart med at enkelte i disse yrkene kan føle seg emosjonelt utmattet i den grad at de selv utvikler et ønske om omsorg (2).

Da pasientene som regel ikke medvirker i forskning, psykiatrisk evaluering eller behandling, er motivasjonen som regel ukjent, og det er meget vanskelig med nærmere beskrivelse og tallfesting av bakenforliggende psykologiske forstyrrelser. I den hittil mest omfattende studien, med analyse av 455 tilfeller fra profesjonell vitenskapelig litteratur, ble en undergruppe på 170 pasienter utredet for psykiatrisk lidelse (3). Komorbid psykopatologi ble funnet hos over $80 \%$ av disse. En aktuell eller tidligere depresjonsdiagnose ble registrert betydelig hyppigere enn personlighetsforstyrrelse (41,8\% versus $16,5 \%)$. På den annen side var i samme undergruppe bare hver syvende pasient aktuelt suicidal eller hadde tidligere suicidforsøk bak seg. I denne undergruppen ble altså en stor andel diagnostisert med depresjon, i kontrast til tidligere oppfatning, hvor man har sett en sterk assosiasjon til personlighetsforstyrrelse (2), spesielt av borderline-type (4).

I tillegg til psykisk sykdom finnes det tallrike enkelteksempler på store og til dels livstruende selvpåførte og/eller iatrogene organiske lidelser (3). Det er også formodet

\section{«Det viktigste verktøy forblir legens sunne forstand»}

at det kan være relativt høy mortalitet på grunn av selvpåført fysisk skade, komplikasjoner etter invasive inngrep og kamuflering av viktig helseinformasjon (5). Pasientene har med andre ord et stort lidelsestrykk.

\section{Klinisk presentasjon}

Symptombilde og kliniske presentasjonsformer varierer stort. Av symptomer, produserte funn og feilaktige tidligere diagnoser referert i litteraturen (3) eller registrert hos våre pasienter kan nevnes: injeksjon av insulin for å frembringe hypoglykemi, angivelse av retrosternale smerter, egenpåførte hudlesjoner, simulering av astmaanfall, egenpåførte cornealesjoner, oppvarming av termometer for febersimulering, tilførsel av blod i urin (enten i urinprøven eller gjennom kateter i blæren), bruk av pupilldilaterende middel for å fremkalle anisokori, medikamenttilførsel for produksjon av hypertensjon eller forandring av blodprøver, selvtapping av blod for produksjon av anemi, produksjon av vaginalblødning, feilaktig anamnese på hiv/aids eller kreft, bruk av turniké for hevelse i en ekstremitet, egenpåført diaré, simulering av epileptisk anfall, koma eller lammelse, angivelse av kroniske smerter og simulering av døvhet eller blindhet.

I den ovennevnte metaanalysen hadde to av tre selvindusert sykdom eller skade (3). Noe mindre hyppig simulerte pasientene sykdom eller opplyste feilaktig om det. Etter vår erfaring innrømmer pasientene sjelden sin simulerende atferd. Når de registrerer at de er ved å bli mistenkt for å være psykisk syk istedenfor å ha en somatisk lidelse, forlater de fleste helseinstitusjonen. Mistanken kan vekkes ved observasjon av et spesielt atferdsmønster (ramme 1) (5).
Pasienter med Münchausens syndrom har ofte startet med sin atferd i tidlig voksen alder, ofte etter et sykehusopphold for somatisk eller psykisk lidelse. I internasjonal litteratur er det forskjellige angivelser når det gjelder kjønnsfordeling. Hyppigst angis en overvekt av menn, andre antyder en overvekt av kvinner $(2,3)$, noe som sammenfaller med våre personlige erfaringer.

\section{Differensialdiagnoser}

Syndromet står i motsetning til enkel simulering, der det foreligger et ønske om ekstern belønning, som å unngå juridiske problemer eller oppnå økonomisk gevinst. Dette tilsvarer på engelsk «malingering»Z76.5 i ICD-10.

Syndromet må også skilles fra somatiseringslidelse, der pasienten over en lengre tidsperiode viser frem fysiske symptomer som ikke er viljestyrt og som oppleves som reelle, uten funn av tilgrunnleggende organisk lidelse. Likeledes antas de mentale og fysiske symptomene ved dissosiative lidelser, i motsetning til ved Münchhausens syndrom, å skje på det ubevisste plan.

\section{Generelle betraktninger}

Det finnes ingen gode insidens- eller prevalensundersøkelser i den generelle befolkningen i internasjonal litteratur. Det er åpenbart store mørketall (6) og nærmest uovervinnelige metodologiske utfordringer.

De fleste leger kvier seg for å mistenke pasienten for simulering. Man er vant med at bedrag og løgn ikke sjelden forekommer i dagliglivet, men som lege er man opplært til nærmest uforbeholdent å stole på pasienten. Når mistanken allikevel er vakt, lar man ofte være å gå videre i den retning av redsel for å overse en organisk diagnose, med de derav følgende negative reaksjoner hos pasienten $o g$ et potensielt erstatningsansvar.

Et mulig enda større hinder er bryet og arbeidsbyrden med å utvide granskingen og overprøve tidligere diagnoser, spesielt når disse er stilt ved andre sykehus. I de fleste tilfeller mener man å kunne unngå videre problemer ved å skrive ut pasienten så raskt som mulig - $\mathrm{i}$ håp om at vedkommende ikke vender tilbake. Resultatet er et enormt misbruk og overforbruk av helsetjenester, og ikke minst risiko for irreversibel pasientskade som følge av unødvendige invasive undersøkelser og gjentatte operasjoner. I en del tilfeller er skadene pasientene blir påført av legebehandling, større enn skadene de påfører seg selv $(2,7,8)$.

Etter våre erfaringer kan ressursbruken hos disse pasientene være større enn hos 


\section{RAMME 1}

Viktige observasjoner som tyder på simulering og fabrikkert sykdom (fra Cruz-Portelles og medarbeidere (5) med tillatelse). Oversatt av forfatterne

Atypisk, dramatisk, vag og ikke-konsistent presentasjon av tilsynelatende plausible symptomer

Pasienten bruker av og til medisinsktekniske uttrykk

Manglende samsvar mellom sykehistorie og objektive funn

Perfekt beskrivelse som ligner på en medisinsk lærebok

Stort antall opphold i forskjellige sykehus og lang sykehistorie

Ansatt i eller erfaring fra helsevesenet

Kontakt med akuttmottaket når de mest erfarne fagfolkene ikke er til stede lferier, kvelder og helger)

Affektavflatet aksept av risikofylte og invasive prosedyrer

Symptomer fremtrer bare når pasienten blir observert

Misbruk av medikamenter, spesiell smertestillende og sedativer

Fiendtlige og kontrollerende pasienter, spesiell hvis de ikke kommer til orde eller når man spør etter deres bakgrunn, medisinsk sykehistorie og dokumentasjon på deres sykdom

Tilsynelatende utvikling av komplikasjoner eller forandring av de opprinnelige symptomer når den foreslåtte sykdommen er utelukket

pasienter med reelle organiske tilstander. Behandling av pasienter med Münchausens syndrom fører ofte til konflikter i avdelingen. Dette reduserer tiden man ellers kunne bruke på andre pasienter. I et forsiktig anslag vil vi tro at omkostningene for hver av våre pasienter gjennomsnittlig har ligget på over 1 million kroner. Dette inkluderer opphold $i$ intensivavdeling og utbetaling fra Norsk pasientskadeerstatning. Disse omkostningene kan sammenlignes med det som er beregnet for USA (2).

Internett og sosiale medier muliggjør nye plattformer for oppmerksomhet, medlidenhet, utagering av sinne eller kontroll av andre (9). Det er skremmende å se hvor lett slike bedrag kan bli utført, hvor vanskelig det er å oppdage opphavspersonen og hvor store skadevirkninger det har for enkelte ofre (10).

Det er viktig å være seg bevisst at også pasienter med Münchhausens syndrom, som alle andre mennesker, kan få en organisk sykdom. Derfor har hver pasient med kjent Münchhausens syndrom som kommer med et tydelig endret symptombilde, rett til å få en solid diagnostisk evaluering. Denne kan kun avkortes dersom man nok en gang kan dokumentere at funnene er fabrikkert. Det store panoramaet av produserte symptomer og funn gjør dette selvfølgelig til en stor utfordring.

Klinikeren kan nå finne støtte i 190 relevante publikasjoner. Det er ut fra disse utarbeidet en relativt lang liste av laboratoriemessige og tekniske hjelpemidler innenfor 13 medisinske områder (11). Listen kan selvfølgelig aldri bli helt komplett, og det viktigste verktøy forblir legens sunne forstand.

\section{Behandlingsmuligheter}

Behandling av pasienter med Münchhausens syndrom er vanskelig, da de fleste unndrar seg en psykiatrisk evaluering. I de få tilfeller der man oppnår kontakt, må behandlingen rettes mot de tilgrunnleggende psykiske problemene.

Dersom det foreligger en nærmere beskrevet psykisk lidelse for hvilken det finnes en spesifikk behandling, for eksempel en alvorlig depresjon, og sykdomsatferden kun er sekundær til denne, kan man behandle den primære lidelsen og håpe at man samtidig kan få pasienten bort fra å simulere sykdom. Det er dog sjelden at man med psykiatrisk og eventuell medikamentell behandling alene kan få motivert pasienten til å slutte med sin selvbeskadigende atferd og dermed sette en stopper for de lidelser vedkommende påfører seg selv og andre.

I Norge har alle innbyggere et personnummer. Dette gir en god identifikasjonsmulighet og relativ høy transparens ved oversending av en fyldig epikrise med diagnosen F68.1 til andre involverte helseinstitusjoner. Vi har fulgt våre pasienter i flere år (i ett tilfelle 15 år) og har kunnet vise at utsending av en detaljert epikrise, ikke bare til primærlegen og henvisende lege eller helseinstitusjon, men til alle helseforetak som pasienten ifølge verifiserte egne opplysninger har hatt kontakt med, har vært utslagsgivende for at vedkommende enten stoppet med sin atferd eller fikk redusert sin aktivitet betydelig.

Utsending av epikriser påført diagnosen F68.1 blir etter våre erfaringer sjelden benyttet av andre leger. Grunnen synes å være at mange føler ubehag ved denne fremgangsmåten - at de slik stigmatiserer pasienten. Imidlertid er etter vår mening det å forsøke å beskytte pasienten mot alvorlige selvpåførte og iatrogene skader, til dels med fare for livet, en etisk sett høyere målsetting enn passivt å akseptere at pasienten fortsetter med sin atferd.

\section{Harald Schrader}

hschjomp@gmail.com

Jan 0. Aasly

Thomas Bøhmer
Harald Schrader (f. 1944) er spesialist i nevrologi og professor dr.med. Han var overlege/professor II ved Nevrologisk avdeling, St. Olavs hospital/Norges teknisk-naturvitenskapelige universitet fra 1987 til han gikk av med pensjon i 2009. Han har erfaring som rettsoppnevnt medisinsk sakkyndig i straffesaker.

Forfatter har fylt ut ICMJE-skjemaet og oppgir ingen interessekonflikter.

Jan O. Aasly (f. 1950) er spesialist i nevrologi og professor dr.med. Han har vært overlege ved Nevrologisk avdeling, Universitetssykehuset Nord-Norge, og er siden 1989 overlege ved Nevrologisk avdeling, St. Olavs hospital/ professor II ved Norges teknisk-naturvitenskapelige universitet.

Forfatter har fylt ut ICMJE-skjemaet og oppgir ingen interessekonflikter.

Thomas Bøhmer (f. 1936) er spesialist i indremedisin og professor dr.med. Han han vært overlege ved Ullevål sykehus og er professor emeritus i klinisk ernæring med fagmedisinsk ansvar ved ernæringslaboratoriet ved Oslo universitetssykehus, Aker.

Forfatter har fylt ut ICMJE-skjemaet og oppgir ingen interessekonflikter.

\section{Litteratur}

1. Asher R. Munchausen's syndrome. Lancet 1951; 1: $339-41$

2. Feldman MD. Playing sick? Untangling the web of Munchausen syndrome, Munchausen by proxy, malingering and factitious disorder. New York: Brunner-Routledge, 2004

3. Yates GP, Feldman MD. Factitious disorder: a systematic review of 455 cases in the professional literature. Gen Hosp Psychiatry 2016; 41: $20-8$.

4. Nadelson T. The Munchausen spectrum: borderline character features. Gen Hosp Psychiatry 1979 1: 11-7.

5. Cruz-Portelles A, Fernández-Chelala BE, PeñaCastillo Y. 31 year old woman with Munchausen syndrome in haemodialysis. Case report and literature review. Nefrologia 2012; 32: 552-3.

6. Ferrara P, Vitelli O, Bottaro $G$ et al. Factitious disorders and Munchausen syndrome: the tip of the iceberg. J Child Health Care 2013; 17: 366-74.

7. Salvo M, Pinna A, Milia P et al. Ocular Munchausen syndrome resulting in bilateral blindness. Eur $J$ Ophthalmol 2006; 16: 654-6.

8. Lin JL, Servat JJ, Bernardino CR et al. Bilateral corneal perforations and autoproptosis as selfinduced manifestations of ocular Munchausen's syndrome. Orbit 2012:31: 252-5

9. Feldman MD. Munchausen by Internet: detecting factitious illness and crisis on the Internet. South Med J 2000; 93: 669-72

10. Pulman A, Taylor J. Munchausen by internet: current research and future directions. J Med Interne Res 2012; 14: e115

11. Kenedi CA, Shirey KG, Hoffa M et al. Laboratory diagnosis of factitious disorder: a systematic review of tools useful in the diagnosis of Munchausen's syndrome. N Z Med J 2011; 124: 66-81.

Mottatt 22.3. 2017, første revisjon innsendt 28.3. 2017, godkjent 5.4. 2017. Redaktør: Ketil Slagstad. Engelsk oversettelse på www.tidsskriftet.no Publisert først på nett. 